С.П. Ярош, Д.О. Гур'єв

Харківський національний університет Повітряних Сил ім. I. Кожедуба, Харків

\title{
АНАЛІЗ РОЗВИТКУ БЕЗПІЛОТНИХ ЛІТАЛЬНИХ АПАРАТІВ, СПОСОБІВ ЇХ БОЙОВОГО ЗАСТОСУВАННЯ ТА РОЗРОБКА ПРОПОЗИЦІЙ ЩОДО ОРГАНІЗАЦІЇ ЕФЕКТИВНОЇ БОРОТЬБИ 3 БЕЗПІЛОТНОЮ АВІАЦІЄЮ
}

У статті проаналізовано напрямки розвитку безпілотної авіаџії, особливо такого типу, як безпілотна ударна авіація, а також ї̈ застосування у останніх збройних конфліктах та тендениії розвитку ії подальшого застосування. Аналіз показав, щзо боротьба сил та засобів протиповітряної оборони в останніх збройних конфліктах проти безпілотної ударної авіачії є недостатньо ефективною внаслідок ряду факторів. Основним з них є випереджальний розвиток даних засобів повітряного нападу по відношенню до існуючих вогневих засобів протиповітряної оборони. 3 метою підвищення ефективності зенітного ракетноартилерійського прикриття об'єктів та угруповань військ запропоновано створення системи боротьби з безпілотною ударною авіацією в частинах, угрупуваннях зенітних ракетних військ.

Ключові слова: безпілотний літальний апарат, безпілотна авіація, безпілотна ударна авіація, баражуючі боєприпаси, зенітне ракетно-артилерійське прикриття, система боротьби, ефективність.

\section{Вступ}

Постановка проблеми. Аналіз воєнних конфліктів останніх років показав, що все більшого значення в них набуває застосування безпілотної авіації (БА). Безпілотна авіація розглядалась як важливий засіб ведення воєнних конфліктів ще 3 середини двадцятого сторіччя. Але на той час вона не набула такого масового поширення та застосовувалась в воєнних конфліктах більше для ведення розвідки, ніж для нанесення ударів. Однією 3 причин цього стали не достатньо розвинуті технології щодо створення безпілотних літальних апаратів (БЛА) різного типу та призначення. 3 розвитком відповідних технологій з'явилась можливість створення БЛА 3 меншими розмірами, але 3 кращими можливостями, щодо ведення розвідки, нанесення ударів. Також з'явився такий тип безпілотної ударної авіації (БУА), як баражуючі боєприпаси (ББ), що значно ускладнило боротьбу з нею засобами та силами протиповітряної оборони (ППО).

Аналіз останніх досліджень і публікацій. Літературні джерела, які були проаналізовані при розробці статті, можливо умовно розділити на ряд взаємопов'язаних груп.

До першої групи публікацій відносяться публікації відносно історії розвитку БЛА та напрямків їх подальшого розвитку [1-6], оскільки завдання протидії ним є взаємопов'язаним з їх розвитком.

До другої групи публікацій відносяться ті, які розкривають способи та досвід застосування БЛА в воєнних конфліктах [3;7-11]. Аналіз даних публікацій дозволяє зрозуміти порядок застосування БЛА, їх ефективність в ході вирішення різних завдань, а також їх сильні та слабкі сторони.
До третьої групи публікацій слід віднести роботи щодо способів боротьби з БЛА [12-14]. Слід відзначити, що широке застосування БЛА, стрімкий їх розвиток в останнє десятиліття призвели до появи значної кількості публікацій, які процес боротьби 3 БЛА розглядають 3 різних позицій: побудови ефективної системи розвідки та РЕБ, боротьби "БЛА" “БЛА”, групового застосування стрілецького озброєння, широкого використання та комплексування зенітного ракетно-артилерійського озброєння, виконання заходів маскування та введення противника в оману.

Але в проаналізованих публікаціях відсутня систематизована на основі досвіду бойового застосування безпілотної авіації інформація щодо шляхів організації ефективної боротьби з БЛА в угрупованнях (частинах) зенітних ракетних військ (ЗРВ).

Мета статті - проаналізувати розвиток безпілотних літальних апаратів, способів бойового застосування безпілотної авіації та запропонувати шляхи організації ефективної боротьби з БЛА в угрупованнях (частинах) ЗРВ.

\section{Виклад основного матеріалу}

\section{1. Розвиток безпілотної ударної авіації}

Необхідність створення БЛА виникла в умовах високих втрат живої сили і техніки, що характерні для сучасних війн. По закінченню Другої Світової війни і до кінця 90-х років ХХ сторіччя БЛА конструювались та використовувались 3 метою ведення розвідки. На них встановлювалось більш досконале обладнання, здатне передавати якісне зображення, для їх запуску та польоту застосовувались нові технології того часу, їх модернізували так, щоб збіль- 
шити висоту польоту, а також зробити більш непомітними для ворожих засобів ППО [1].

Науково-технічний прогрес наприкінці 90-х початку 2000-х не обійшов і БЛА. На фоні розробки нових технологій передачі та обробки інформації, появи нової елементної бази, їх виробництво стало здешевлюватись, а їх функціонал покращуватися, в наступних напрямках [1-2]:

а) збільшення дальності польоту, тобто збільшення корисної дії двигуна, а також зменшення його акустичного шуму (поява БЛА з електродвигунами), збільшення енергоємності елементів живлення;

б) покращення систем навігації, управління (зв'язку);

в) вдосконалення планера щодо зменшення ваги, розмірів, ефективної площі розсіювання (ЕПР);

г) вдосконалення засобів вогневого впливу, які встановлюються на БЛА (на початку 2000-х на БЛА стали встановлювати керовані ракети);

д) вдосконалення засобів невогневого впливу (засобів радіоелектронної боротьби (РЕБ)), які встановлюються на БЛА;

е) вдосконалення засобів розвідки (радіотехнічної, оптико-електронної, інфрачервоної);

ж) вдосконалення систем фото та відео спостереження.

Внаслідок відповідного розвитку змінилась сама концепція застосування БЛА. Так, велику роль під час збройних конфліктів стала відігравати безпілотна ударна авіація. Треба сказати, що деякий час самим відомим БЛА БУА був американський MQ-1 "Predator", пізніше на його базі створили більш важкий MQ-9 “Reaper", це достатньо великі та важкі БЛА.

Зараз основним класом БУА, який застосовують сучасні армії світу, є БЛА середнього класу, які прийнято позначати за допомогою абревіатури MALE, що розшифровується, як "medium altitude, long endurance” (БЛА здатні працювати тривалий час на середній висоті). Їх цінність полягає в можливості тривалий час знаходитися у визначеній зоні очікуючи виклик, що дає їм можливість залишатися поза полем бою (поза зоною вогневого впливу засобів ППО), але з невеликим підльотним часом. Одним із найбільше відомих БЛА цього класу є турецький "Bayraktar ТВ2". Порівнюючи ТТХ БЛА можна побачити, що "Bayraktar ТВ2" може знаходитись в повітрі до однієї доби, а в 3,5 рази важчий MQ-9 “Reaper" - до 14 годин. При цьому MQ-9 "Reaper" здатен нести до 1,7 тон корисного навантаження. “Bayrektar ТВ2” здатен нести всього 150 кг, але і цього виявилось достатньо для ефективного застосування в бойовій обстановці [3]. БЛА класу MALE “Bayraktar TB2” добре проявили себе під час збройних конфліктів в Сирії та Нагорному Карабасі, тобто змогли з високою ефективністю виконувати ті завдання, які покладались на більш важкі БЛА [3].
Іншим типом БЛА який розвивається найбільш активно, є баражуючі боєприпаси. Розробка цих БЛА в широких масштабах стала можливою завдяки досягненням в створенні мініатюрних економічних двигунів, високоточних систем наведення, малогабаритних бортових цифрових обчислювальних машин та ін. Апарати цього класу мають малу ЕПР, низькі значення рівнів шуму і теплового випромінювання. Баражуючі боєприпаси являють собою свого роду крилаті ракети, які здатні баражувати 6-9 годин в районі очікування. Вони мають сучасну систему навігації та прицілювання, здатні наводитись на ціль та тримати іiі в прицілі маневруючи на підльоті до неї на швидкості до 550 км/год. Наприклад, ББ “Orbiter III" може баражувати 6-8 годин, його бойова частина важить всього 3 кг. "Skystriker" більше важкий, його бойова частина може мати вагу до 10 кг.

Боєприпас, що баражує, може знищувати значно дорожчі зразки озброєння ЗРК (ЗРГК), ракетні комплекси, танки [3]. В табл. 1 приведені вартісні показники ББ та інших зразків озброєння [15-16].

Таблиця 1

Вартісні показники БЛА

та інших зразків озброєння

\begin{tabular}{|c|c|c|c|c|c|}
\hline $\begin{array}{l}\text { Тип } \\
\text { ОВТ }\end{array}$ & \multicolumn{2}{|c|}{$\begin{array}{c}\text { Баражуючий } \\
\text { боєприпас }\end{array}$} & Танк & \multicolumn{2}{|c|}{ ЗРК(ЗРГК) } \\
\hline Назва & 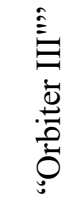 & 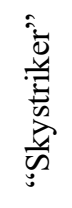 & 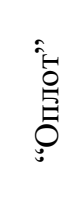 & 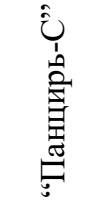 & : \\
\hline $\begin{array}{l}\text { Bap- } \\
\text { тість, } \\
\text { тис. \$ }\end{array}$ & $\begin{array}{l}\text { біля } \\
700\end{array}$ & $\begin{array}{l}\text { біля } \\
250\end{array}$ & $\begin{array}{c}\text { біля } \\
4900\end{array}$ & $\begin{array}{c}\text { біля } \\
14000\end{array}$ & $\begin{array}{c}\text { біля } \\
12000\end{array}$ \\
\hline
\end{tabular}

Джерело: розроблено авторами.

Врахуванням напрямків розвитку сучасних технологій можливо спрогнозувати, що напрямками подальшого розвитку БЛА будуть покращення їх авіоніки, технічних характеристик, систем зв'язку, тривалості та дальності польоту. Значна увага при створенні нових БЛА приділяється автономності, стійкості до впливу РЕБ системи управління, покращенню алгоритму обробки зображень і системи відеоспостереження. Покращення технічних характеристик дозволить застосовувати БЛА в колективах (роях), при цьому управління діями цих колективів буде здійснюватись не тільки за рахунок роботи операторів, але і з використанням "штучного інтелекту”. Також надалі слід чекати вдосконалення взаємодії безпілотних систем 3 іншими видами ОВТ і силами (сили спеціальних операцій, пілотована авіація). Застосування відповідних підходів до створення та застосування БУА значно ускладнить боротьбу з нею силами та засобами ППО [1-6]. 


\section{2. Застосування безпілотної ударної авіації В збройних конфлліктах}

Нова концепція повітряно-наземного бою передбачає використання БА замість класичної авіації й вертольотів. БА слід сприймати як одну з можливих опцій для поля бою у визначених умовах, наприклад, коли використання власної авіації є неможливим або недоцільним. Не меншого значення має можливість уникнути втрат особового складу. БА дедалі активніше використовуватимуться для розвідки противника, наведення й координації вогню артилерії, здійснення автономних високоточних атак [7].

Найбільш масово БА була застосована під час збройних конфліктів в Сирії, Лівії та Нагорному Карабасі [3; 7].

Під час збройного конфлікту в Сирії (операції “Щит Єфрату” (2016р.), “Оливкова гілка” (2017р.), “Джерело миру”(2019 р.), “Весняний щит” (2020р.)) основними типами БЛА, які застосувала Турецька армія, були: ударний БЛА "Bayraktar ТВ2" та багатоцільовий “Anka-S”, що несли високоточні боєприпаси (MAM-L i MAM-C).

БА в Сирії виконувала завдання розвідки, спостереження, наведення й коригування вогню артилерії та нанесення ударів.

Застосування БЛА відбувалося за підтримки систем радіоелектронної боротьби (РЕБ), а також ствольної та реактивної артилерії (Т-155 "Firtina", T-122 "Sakarya", T-300 "Kasirga"). Зазвичай БА виконувала атаки 3-поза меж досяжності легких систем протиповітряної оборони 3 надзвичайною точністю. Одночасне використання артилерії та БА сприяло тому, що в межах досяжності турецьких засобів пораження опинилася не лише лінія фронту, а й глибокі тили противника. Для знищення кожної виявленої цілі було зарезервовано більше, ніж один БЛА, що значно підвищувало ефективність ударів і шанси на пораження системи ППО загалом. БЛА “Anka-S”, що стартували 3 території Туреччини, здійснювали розвідку цілей і передавали інформацію до станцій РЕБ “Koral”, розміщених біля кордону. Тi, своєю чергою, активно впливали на роботу сирійських засобів ППО, передусім виконували постановку завад і введення в оману операторів РЛС противника. Після подавлення ППО для атаки використовували ударні БЛА Bayraktar ТВ2 з високоточними боєприпасами (MAM-L) [7].

В результаті операції "Весняний щит" було знищено до 8 сучасних зенітних ракетно-гарматних комплексів “Панцирь-С” виробництва РФ. Цікаво те, що російські розробники останнім часом особливо наголошували на здатності комплексу успішно боротися саме з БЛА. Щодо втрат турецьких сил, то повідомлялося про знищення 14 (за іншими даними — до 10) БЛА, переважно “Anka-S” [7-9].
Особливістю воєнного конфлікту в Нагорному Карабасі стало те, що обидві сторони обмежено застосовували пілотовану авіацію в наслідок того, що 3 обох сторін була побудована система ППО та застосовувались ЗРК (ЗРГК) [3; 10$]$.

В цілому угрупування БА Азербайджану нараховувало до 120 БЛА (розвідки, багатоцільових, ударних) та до 400 одиниць боєприпасів, що баражують. Літаки Ан-2 з дистанційним керуванням - 60 одиниць, які застосовувались в якості приманки для розтину ППО [1; 10-11].

БА виконувала завдання: подолання ППО та завоювання панування у повітрі, нанесення ударів по наземним цілям в тактичній зоні та оперативній глибині, ізоляції району бойових дій, повітряної розвідки, цілевказання та корегування вогню артилерії, забезпечення зв'язку, радіоелектронної розвідки та радіоелектронного подавлення.

В ході операції для виконання задач було створено 10-12 тактичних груп БЛА, які діяли в призначених районах відповідальності. БЛА здійснювали баражування в 50 км від лінії зіткнення та вступали в бій безпосередньо перед наземною атакою. Один апарат, який діяв на висотах 8-9 км, здійснював загальний контроль обстановки та управління групою. На висотах 6-7 км діяли розвідувально-ударні БЛА, ретранслятори, БЛА радіоелектронної розвідки. На малих та гранично малих висотах діяли баражуючи боєприпаси. В цілому на першому та другому етапах в повітрі одночасно діяли щодоби до 100 БЛА $[1 ; 10]$.

Тобто, в Нагорному Карабасі відбулося більш масове загалом та більшими групами в ході виконання конкретних завдань застосування БА, ніж в Сирії.

Провівши аналіз бойових втрат переможеного Вірменії, можна зробити висновок, що від 60 до 90\% завдань вогневого пораження було покладено на авіацію ЗС Азербайджану, незважаючи на наявність достатньо потужного угруповання ракетних військ та артилерії [1; 10-11].

Важливим фактором також було те, що Азербайджан переміг не тільки на полі бою, але і в інформаційному просторі, за рахунок знятих камерами БЛА кадрів щодо знищення сил та засобів збройних сил Нагорного Карабаху. При цьому протиставити Нагорному Карабаху було нічого внаслідок того, що у підрозділах ППО на засобах пораження повітряних цілей (ракетах, снарядах) відсутні відео-(фото) камери [1; 10].

Отже, 3 кожним новим воєнним конфліктом можливо відмітити значне збільшення ефективного застосування БУА. При цьому найбільш небезпечними для сил та засобів ППО виявився такий тип БУА, як баражуючі боєприпаси. 


\section{3. Пропозиції щодо підвищення ефективності боротьби з безпілотною ударною авіацією}

В ході операції для боротьби з БУА застосуються пасивні та активні заходи протидії. Пасивні та активні заходи боротьби з БУА здійснюються застосуванням відповідних сил та засобів: РЛС, ЗРК (ЗРГК), комплексів РЕБ, засобів безпосереднього прикриття, стрілецької зброї різних типів, а також виконанням заходів бойового забезпечення [4; 12 13]. Але із викладеного вище можна зрозуміти, що виконання цих заходів $є$ недостатнім та поки що не $\epsilon$ комплексним. Зазначені сили та засоби є недостатньо ефективними та застосовуються також і для виконання інших заходів, наприклад, боротьба 3 наземним противником (ДРГ).

Основними факторами недостатньої ефективності системи зенітного ракетно-артилерійського прикриття (ЗРАП), щодо боротьби з безпілотною ударною авіацією, є:

- наявність достовірної інформації про розміщення засобів ППО та обізнаність про порядок їх застосування у повітряного противника (БЛА) та не достатня наявність інформації (обізнаність про порядок дій авіації противника) у сил ППО;

- комплексне застосування БЛА різних типів та призначення;

- активне застосування таких типів бойової ударної авіації, як баражуючі боєприпаси, які діють одночасно 3 різних напрямків, мають ЕПР $\left(0,01 \ldots 0,02 \mathrm{~m}^{2}\right)$. При цьому, тактико-технічні характеристики наявних у Нагорного Карабаху ЗРК (ЗРГК) (до речі, за типами вони такі самі як стоять на озброєнні ЗС України) не дозволяють їм своєчасно виявити та обстріляти баражуючи боєприпаси;

- наявність у зоні пораження кожного ЗРК такого поняття, як ближня межа зони пораження та “мертва воронка";

- неефективне безпосереднє прикриття 3 причини невідповідності можливостей залучених сил та засобів безпосереднього прикриття технічним характеристикам БУА та відсутності навичок бойових обслуг вогневих засобів ППО в боротьбі з сучасними типами БУА.

Що стосується засобів ППО СВ, таких як ЗРК (ЗРГК) “Тор-М1”, “Оса”, “Оса-АКМ”, “Тунгуска”, “Стрела-10”, які мають відносно недорогі засоби пораження, призначені відповідно до бойових статутів для знищення, в тому числі, малорозмірних цілей, створювались 3 метою безпосереднього прикриття військ і навіть розглядаються, як засоби безпосереднього прикриття ЗРК середньої дальності та дальньої дії, то слід зазначити, що вони виявились недостатньо ефективними в боротьбі з БУА [1-4; 7-12].

Для побудови ефективної системи боротьби 3 БА необхідно використовувати іiі слабкі сторони, такі, як:

1) уразливість БЛА від вогню засобів ППОПРО та винищувальної авіації;

2) погодозалежність, наявність ряду демаскуючих ознак (електромагнітне, інфрачервоне, акустичне та радіовипромінювання), а також чутливість до впливу завад і “хакерських" атак [4];

3) недостатньо відпрацьована взаємодія при спільному застосуванні пілотованої та безпілотної авіації.

Існує думка, що на сьогоднішній день жодна держава не готова протистояти спланованим атакам БЛА. Традиційні види озброєння ППО розраховані на великі і віддалені цілі, в той час як сучасна лінійка БЛА складається 3 нано-, мікро- і міні-апаратів, що літають на малих висотах [3].

Не дивлячись на те, що США значно випереджають інші країни у розвитку воєнної БА, їх експерти вважають, що ЗС США потенційно вразливі для ударів БУА інших країн. У 2020 році в Пентагоні провели дослідження, за підсумками якого зробили висновок, що в американській армії немає системного підходу до організації оборони від ударів БЛА середнього та малого класу. За словами спеціалістів, в кожному виді ЗС США $є$ відповідні тактичні напрацювання по боротьбі з БЛА. Однак Пентагон хоче відпрацювати загальну для всіх концепцію боротьби з подібними загрозами [3].

Виходячи з викладеного, можливо зробити висновок, що необхідно розробляти (або закуповувати) нові засоби ППО з характеристиками, які дозволяють вести ефективну боротьбу з БА (ББ).

Прийняття на озброєння нових ЗРК (ЗРГК) $є$ складним та тривалим процесом. При цьому відсутня гарантія, що на момент прийняття розробленого ЗРК його характеристики будуть відповідати характеристикам перспективних ЗПН. Придбання нових засобів потребує значних фінансових ресурсів. Тому, в найближчій перспективі потрібно досліджувати інші методи та способи підвищення ефективності системи ЗРАП, щодо боротьби з БЛА (ББ).

Одним із таких методів може бути створення системи боротьби з БУА. Ця система повинна включати в себе декілька складових (рис. 1). Основними складовими цієї системи повинні стати:

1) підсистема управління силами та засобами боротьби з БУА;

2) підситема розвідки;

3) підсистема вогневого впливу;

4) підсистема РЕБ;

5) підсистема безпілотного прикриття;

6) підсистема інженерного забезпечення;

7) підсистема маскування та введення в оману.

Основним фактором, який дозволить підвищити ефективність зенітного ракетного (ракетноартилерійського) прикриття завдяки створенню та 
впровадженню цієї системи, є створення умов для невизначеності повітряного противника щодо: складу сил та засобів, що йому протидіють; бойового порядку вогневих підрозділів ППО; порядку застосування засобів ППО.

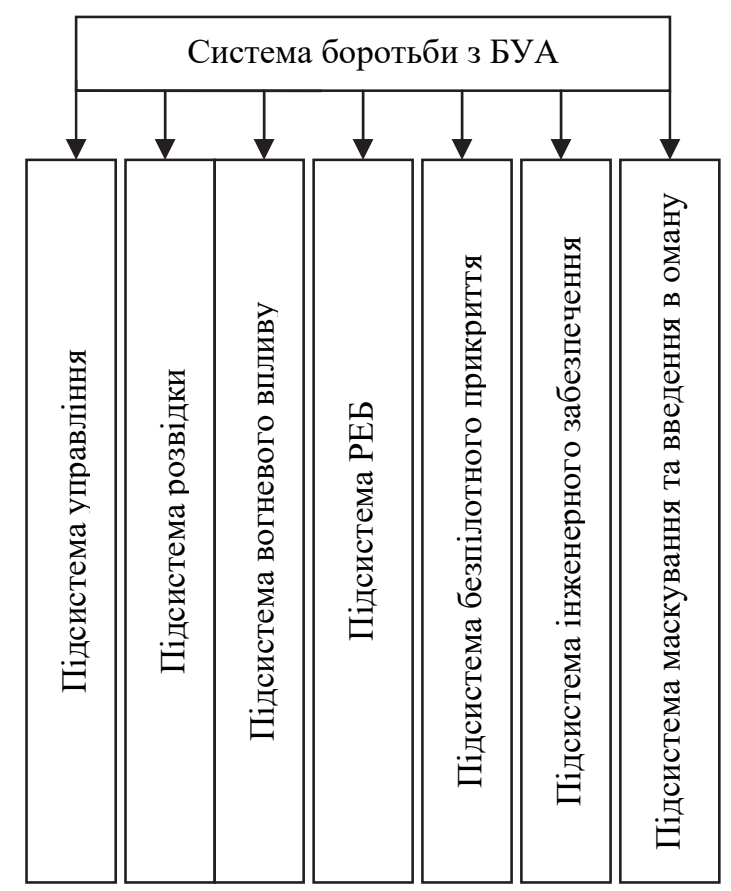

Рис. 1. Система боротьби з БУА

Джерело: розроблено авторами.

Позитивний ефект буде досягнутий також завдяки комплексному застосуванню вогневих та не вогневих (РЕБ) засобів боротьби з БУА (активна та пасивна ППО - відповідно до стандарту NATO AJP3.3.1(8)) [13].

Невизначеність противника про створену систему боротьби з БУА буде досягатись за рахунок комплексного вирішення завдань, таких як розвідка повітряного противника, вогневий вплив, невогневий вплив РЕБ з різних позицій одночасно, зі зміною цих позицій за визначеним алгоритмом відповідно до обстановки.

3 метою забезпечення управління силами та засобами створеної системи необхідно застосовувати завадостійкі засоби зв'язку та сучасні засоби відображення інформації.

Забезпечення інформацією про повітряного противника повинно здійснюватись в єдиній інформаційній мережі, створеній з застосуванням завадостійких засобів зв'язку та відображення інформації. Створення інформаційної мережі дозволить рознести в просторі позиції вогневих засобів, засобів РЕБ та радіолокаційної розвідки.

Для ведення радіолокаційної розвідки БА необхідно залучити додаткові високомобільні малогабаритні РЛС різних діапазонів хвиль 3 дальністю дії близько 50 км, які спроможні працювати по цілям 3
ЕПР 0,01 м². Позиції РЛС, які працюють в системі боротьби з БУА, не повинні співпадати з позиціями вогневих засобів та засобів РЕБ, що повинно підвищити живучість системи в цілому. При цьому кожний вогневий та невогневий засіб ППО буде отримувати в режимі реального часу інформацію про повітряного противника. Важливими характеристиками для таких РЛС крім дальності виявлення та можливості виявлення малорозмірних цілей $є$ електромагнітна сумісність з основними засобами розвідки підрозділів ЗРВ та військ ППО СВ, висока мобільність, а також можливість спряження з сучасними засобами зв'язку та відображення інформації. Також ефективними засобами розвідки будуть пасивні ІЧкамери та акустичні датчики.

Щодо застосування вогневих засобів, то ефективним буде комплексне застосування різних засобів безпосереднього прикриття, а також використання боєприпасів 3 програмованим повітряним підривом $[4 ; 12 ; 14]$. При цьому, для ведення ефективної боротьби гарматно-стрілецьким озброєнням безпосереднього прикриття необхідно мати: АСУ вогнем гарматних засобів (одна АСУ на $3 . .6$ засобів); РЛС гарматного наведення; комплекс прицілювання у складі оптичного, телевізійного та інфрачервоного прицілів та лазерного далекоміра.

Як не вогневі засоби пропонується застосовувати переносні, мобільні комплекси РЕБ для протидії БЛА, які здатні заглушувати канали їх управління, здійснювати спуфінг, виводити з ладу електронне обладнання БЛА [4; 12].

Не менше важливим фактором є створення підсистеми інженерного забезпечення боротьби з БУА. Окрім ретельного виконання заходів інженерного обладнання позицій, маскування, створення хибних позицій повинно бути замовлено виготовлення різнотипних макетів озброєння для введення противника в оману.

Створення системи боротьби з БУА дозволить підвищити ефективність зенітного ракетноартилерійського прикриття об'єктів та угруповань військ в цілому.

\section{Висновки}

1. Розвиток засобів БУА та тактики її застосування вимагає створення сил та засобів, які можуть ефективно боротись 3 нею. Шляхами підвищення ефективності ППО при цьому є прийняття на озброєння нових зразків ОВТ, що є довготривалим процесом, або систематизація боротьби з БА тими силами та засобами, що існують.

2. Для створення системи боротьби з БУА в частині, угрупуванні ЗРВ необхідно визначити оптимальний склад сил та засобів ії підсистем для виконання цього завдання, а також визначити порядок взаємодії цих підсистем в ході протиповітряного 
бою. Створення системи боротьби з БУА дозволить підвищити ефективність зенітного ракетно-артилерійського прикриття об'єктів та угруповань військ в цілому.

3. Напрямком подальших досліджень повинна стати розробка методичного апарату для обгрунтування створення та застосування системи боротьби 3
БУА у складі: комплексної методики обгрунтування складу сил та засобів системи боротьби з БУА (за всіма підсистемами); методики визначення способів взаємодії підсистем системи боротьби з БУА; методики оцінки ефективності функціонування системи боротьби з БУА.

\section{Список літератури}

1. Гришина Ю.С. Дроны на службе миру [Електронний ресурс] / Ю.С. Гришина // Робототехника и системный анализ. - 2015. - Вип. 1. - Режим доступу: http://www.penzgtu.ru/fileadmin/filemounts/science/konf_roganov /robototehnika83.pdf.

2. Евтодьева М.Г. Беспилотные летательные аппараты военного назначения: тенденции в сфере розработок и производства [Електронний ресурс] / М.Г. Евтодьева, С.В. Целицкий // Вооружения и военная техника. - Режим доступу: https://www.imemo.ru/files/File/magazines/puty_miru/2019/02/09-Yevtodieva.pdf.

3. Офиційний сайт BBS News. Война будущего. Как конфликт в Карабахе повлияет на развитие военных беспилотников. - Режим доступу: https://www.bbc.com/features-54923381.

4. Сучасний стан та проблеми протидії маловисотним, низькошвидкісним та малорозмірним БПЛА [Електронний pecyрс] / А.С. Дудуш, В.О. Тютюнник, О.А. Резніченко, С.Ю. Гогонянц. - Режим доступу: http://sit.nuou.org.ua/article/download/159095/158399.

5. Alexeev Alex. Настоящее и будущее беспилотной авиации. Часть 1 [Електронний ресурc] / Alex Alexeev // Boeнное обозрение. - 2016. - 25 янв. - Режим доступу: https://topwar.ru/89642-nastoyaschee-i-buduschee-bespilotnoy-aviaciichast-1.html (дата звернення: 14.01.2020).

6. Alexeev Alex. Настоящее и будущее беспилотной авиации. Часть 2 [Електронний ресурс] / Alex Alexeev // Boeнное обозрение. - 2016. - 28 янв. - Режим доступу: https://topwar.ru/89909-nastoyaschee-i-buduschee-bespilotnoy-aviaciichast-2.html (дата звернення: 14.01.2020).

7. Заблоцький В. Які особливості мала турецька операція “Весняний щит” у Сирії. (Дроноцентричний удар) [Електронний ресурс] / В. Заблоцький // Defense express. - 2020. - Режим доступу: https://defenceua.com/weapon_and_tech/dronotsentrichnij_udar-457.html.

8. Коваленко А. Российские ЗРК линейки малой и средней дальности оказались бесполезными против малогабаритных ударних БПЛА [Електронний ресурс] / А. Коваленко // Одесский курьер. - 19.12.2020. - Режим доступу: https://uc.od.ua/columns/1533/1231999.

9. Пораховано, скільки “Панцирь С1" втрачено у Сирії та Лівії [Електронний ресурс] // Defense express. - 2020. Режим доступу: https://defenceua.com/news/porahovano_skilki_rosijskih_pantsir_s1_vtracheno_v_siriji_ta_liviji-915.html.

10. Аксенов П. Война дронов в Карабахе: как беспилотники изменили конфликт между Азербайджаном и Арменией [Електронний ресурс] / П. Аксенов. - Режим доступу: https://www.bbc.com /russian/features-54431 129.

11. Михненко А. Як ударні турецькі дрони змінили тактику війни [Електронний ресурс] / А. Михненко. - Режим доступу: https://defencea.com/weapon_and_tech/jak_udarni_turetski_droni_zminili_taktiku_vijni-342.html.

12. Растопчин В.В. Ударные беспилотные летальные аппараты и противовоздушная оборона - проблемы и перспективы противостояния [Електронний ресурс] / В.В. Растопчин. - 2019. - Режим доступу: https://www.researchgate.net/publication/331772628_Udarnye_bespilotnye_letatelnye_apparaty_i_protivovozdusnaa_oborona_p roblemy_i_perspektivy_protivostoania.

13. Стандарт NATO AJP-3.3.1(8). ALLIED JOINT DOCTRINE FOR AIR AND SPACE OPERATIONS. - 2016.

14. Аналіз сучасних засобів знищення безпілотних літальних апаратів [Електронний ресурс] / Р.В. Корольов, Н.О. Королюк, О.В. Петров, К.В. Сюлев // Ukrainian military pages. - Режим доступу: https://www.ukrmilitary.com/2017/10/zasoby-proty-bpla.html.

15. Лискович М. Ударные беспилотники: покупаем “Байрактары”, а свои, более мощные, никак не доделаем [Електронний ресурс] / М. Лискович // Укринформ. - Режим доступу: https://www.ukrinform.ru/rubric-technology/3146014udarnye-bespilotniki-pokupaem-bajraktary-a-svoi-bolee-mosnye-nikak-ne-dodelaem.html.

16. Фетудинов Д. Беспилотники в карабаском конфликте 24.11.2020 Електронний ресурс] / Д. Фетудинов. - Режим доступу: https://russiancouncil.ru/analytics-and-comments/analytics/bespilotniki-v-karabakhskom-konflikte.

\section{Відомості про авторів:}

\section{Ярош Сергій Петрович}

доктор військових наук професор

професор кафедри

Харківського національного університету

Повітряних Сил ім. І. Кожедуба,

Харків,Україна

https://orcid.org/0000-0002-5208-9372

\section{Information about the authors:}

\section{Sergey Yarosh}

Doctor of Military Sciences Professor

Professor of the Department

of Ivan Kozhedub Kharkiv National

Air Forc University,

Kharkiv, Ukraine

https://orcid.org/0000-0002-5208-9372 
Гур'єв Дмитро Олександрович

начальник науково-дослідного відділу

Харківського національного університету

Повітряних Сил ім. І. Кожедуба,

Харків, Україна

https://orcid.org/0000-0002-2469-0865

\section{Dmytro Huriev}

Head of Scientific Research Department

of Ivan Kozhedub Kharkiv National

Air Force University,

Kharkiv, Ukraine

https://orcid.org/0000-0002-2469-0865

\title{
АНАЛИЗ РАЗВИТИЯ БЕСПИЛОТНЫХ ЛЕТАТЕЛЬНЫХ АППАРАТОВ, СПОСОБОВ ИХ БОЕВОГО ПРИМЕНЕНИЯ И РАЗРАБОТКА ПРЕДЛОЖЕНИЙ ПО ОРГАНИЗАЦИИ ЭФФЕКТИВНОЙ БОРЬБЫ С БЕСПИЛОТНОЙ АВИАЦИЕЙ
}

\author{
С.П. Ярош, Д.А. Гурьев
}

В статье проанализировано направление развития беспилотной авиации, особенно такого типа, как беспилотная ударная авиация, а также ее применение в последних военных конфликтах и тенденции развития ее дальнейшего применения. Анализ показал, что борьба сил и средств противовоздушной обороны в последних военных конфликтах против беспилотной ударной авиации недостаточно эффективна вследствие ряда факторов. Основным из них является опережение в развитии данных средств воздушного нападения по отношению к существуюшим огневым средствам противовоздушной обороны, что подразумевает разработку и создание новых средств противовоздушной обороны с характеристиками, которые позволят вести эффективную борьбу с беспилотной авиацией, но это очень сложный и длительный процесс. Также важным фактором является то, что силы и средства, которые выделяются для борьбы с беспилотной авиацией, недостаточны, и их применение несистематизировано. С целью повышения эффективности зенитного ракетно-артиллерийского прикрытия объектов и группировок войск предложено создание системы борьбы с беспилотной ударной авиацией в частях, группировках зенитных ракетных войск. Эта система отвечает приниипу комплексного применения огневых и не огневых средств (применения активной и пассивной противовоздушной обороны) - в соответствии со стандартом НАTO NATO AJP-3.3.1(8) и будет включать в себя ряд подсистем. Основным фактором, который позволит повысить эффективность зенитного ракетно-артиллерийского прикрытия, благодаря созданию и применению этой системы, будет создание условий для неопределенности воздушного противника о: составе сил и средств, которые ему противодействуют; боевому порядку огневых подразделений противовоздушной обороны; порядку применения средств противовоздушной обороньл.

Ключевые слова: беспилотный летательный аппарат, беспилотная авиация, беспилотная ударная авиация, барражирующий боеприпас, зенитное ракетно-артиллерийское прикрытие, система борьбы, эффективность.

\section{ANALYSIS OF THE DEVELOPMENT OF UNMANNED AIRCRAFT, METHODS OF THEIR COMBAT APPLICATION AND DEVELOPMENT OF PROPOSALS FOR THE ORGANIZATION OF EFFECTIVE COMBAT AGAINST UNMANNED AVIATION}

\author{
S. Yarosh, D. Huriev
}

The article analyzes the direction of development of unmanned aircraft, especially of this type, as unmanned strike aircraft, as well as its application in recent military conflicts and development trends of its further use. The analysis showed that the struggle of forces and means of air defense in recent military conflicts against unmanned strike aircraft is insufficiently effective due to a number of factors. The main one is the advancement in the development of these air attack weapons in relation to the existing air defense weapons, which implies the development and creation of new air defense weapons with characteristics that will allow an effective fight against unmanned aircraft, but this is a very complex and lengthy process. Another important factor is that the forces and means allocated to combat unmanned aircraft are insufficient and their use is unsystematic. In order to increase the effectiveness of anti-aircraft missile and artillery cover of objects and groupings of forces, it is proposed to create a system for combating unmanned strike aircraft in units and groupings of anti-aircraft missile forces. This system meets the principle of the integrated use of fire and non-fire weapons (the use of active and passive air defense) - in accordance with NATO NATO AJP-3.3.1 (8) and will include a number of subsystems. The main factor that will make it possible to increase the effectiveness of anti-aircraft missile and artillery cover, thanks to the creation and use of this system, will be the creation of conditions for the uncertainty of the air enemy about: the composition of the forces and means that they oppose; the order of battle of air defense fire subunits; the procedure for the use of air defense means.

Keywords: unmanned aerial vehicle, unmanned aircraft, unmanned attack aircraft, barrage munitions, anti-aircraft missile and artillery cover, combat system, efficiency. 